\title{
Politicians recognise falling dentist income
}

Politicians in Northern Ireland have acknowledged that dentist income has fallen over the past decade, according to BDA Northern Ireland (NI).

The union received a letter on 12 October 2018 from the Department of Health's Permanent Secretary, Richard Pengelly, which acknowledged 'there has been a material reduction in dentist income over the last 10 years.

Responding to a previous letter sent by BDA NI, Pengelly said it was unclear how much of this related to the health service and how much of it was a reduction in private income.

The BDA wrote to Pengelly asking that the Department put in place a dedicated work stream aimed at addressing the legacy of almost a decade of falling dental incomes and rising expenses.

In response, Pengelly said he would welcome any exploratory work the BDA might wish to undertake to gather evidence of increases in costs or reductions in incomes from dentists to support discussions between the BDA, the Department and the Health and Social Care Board.

Northern Ireland Dental Practice Committee Chair Richard

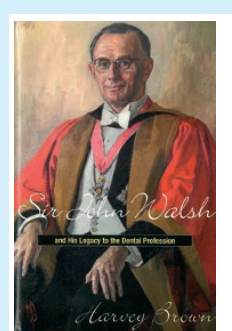

\section{SIR JOHN WALSH AND HIS LEGACY TO THE DENTAL PROFESSION}

\section{Harvey Brown}

2017; Sir John Walsh Biography Fund Trust

pp. 269

ISBN: 978-0473394158

Sir John Walsh was Dean of the Faculty of Dentistry, University of Otago, New Zealand, from 1946 to 1971. Knighted in 1961 for his services to the profession and the community, he became an international figure in dentistry and was included in the FDI's list of Honour in 1985. This book traces his life from underprivileged beginnings to international acclaim.

The first chapter describes his humble origins from Irish immigrants to Australia in the 1860s. Born in 1911 in Melbourne, Australia, the eldest son of an alcoholic father and office cleaner, John Walsh had a very difficult upbringing. He left school at twelve and became apprenticed to a dental mechanic. He educated himself through night classes and at 21 was accepted into the University of Melbourne Dental School with a scholarship. He married Enid while still a student at the age of 23. Every exam he took he passed with honours. After qualification he was asked to join the staff but soon applied to study medicine with his studies financed through his own dental practice. He qualified in medicine in1943. By 1946 he was appointed Dean of the New Zealand's only dental school in Dunedin, a faculty of the University of Otago.

The next two chapters describe Walsh's battle with the university, local authorities and government to bring the dental school from its run-down state to a modern facility. It took him until 1961 when the new school was opened.

Walsh became recognised as an inspiring teacher, researcher and communicator during these years. Chapter 4 describes his time as
Graham said: 'It is a positive development that the Permanent Secretary has acknowledged there has been a reduction in dentist income over the past decade, and that this has been materially significant.

'We also welcome the opportunity offered to us to engage directly with officials around evidence of increased costs and reduced incomes.

'Quite simply, it costs GDPs far more now to deliver Health Service dentistry than it did 10 years ago; expenses have increased at a far faster rate than pay uplifts, resulting in average taxable income falling by $38.1 \%$ for practice owners, and by $28.2 \%$ for associates between 2008-09 and 2016-17 in real terms. Clearly, this is not sustainable.'

The union would be stepping up its engagement with Department in the coming months, he added, saying: 'We will be making a robust case in favour of adequate remuneration for the real cost of delivering Health Service dentistry. Particularly as another significant underspend in the GDS looks likely, the Department of Health has a duty to be forthcoming with additional investment.'

editor of the New Zealand Dental Journal from 1946 to 1953 where his editorials had a great influence on the teaching and practice of dentistry. The following chapter describes his research in the development of the dental turbine handpiece. Chapter 8 discusses his teaching philosophy, which is a 'must read' even for students today.

Just before the new school opened, John Walsh received a knighthood. Chapter 6 describes life in the new school - a modern facility comparing well with overseas schools. The move to the new school gave the opportunity for change in the dental curriculum and to establish more research. Training of dental assistants and hygienists was initiated. During this time he became influential internationally with his visions for dentistry and dental education (Chapter 7). However, his huge workload took its toll on his health and he had a stroke in 1968 and a dissecting aortic aneurysm in 1970. He retired at the age of 60 . Remarkably, he died at the age of 93 .

Chapter 9, 'Service to the Community', explains how his opinions and influence spread far outside the dental school to many kinds of community groups. He was elected to the Dunedin City Council in 1968 and served for five years. He was a forceful influence in Rotary, Alcoholics Anonymous, and the United Nations Association and had a public following as a television personality - all well into retirement.

Chapters 10 and 11 give student and family insights into his life and these are followed by a chapter in appreciation of his legacy.

This is a very readable book about the remarkable career of a remarkable man. In these days where the disadvantaged are claimed to have no prospects in life, Sir John's career is an inspiration showing what can be done with intelligence, drive, dedication, and determination. Dental students looking to achieve professional excellence and motivation could do well to study this book. However, Sir John's life could be taken as an example of what can be done from humble beginnings and this book deserves a wider readership.

Richard Juniper 